\title{
Expertise on the Anglophone Crisis in Cameroon: A Hybrid Cultural Boundary Approach
}

\section{Mireille Manga Edimo}

\section{(2) OpenEdition}

1 Journals

Electronic version

URL: https://journals.openedition.org/irpp/2324

DOI: 10.4000/irpp.2324

ISSN: 2706-6274

Publisher

International Public Policy Association

\section{Printed version}

Date of publication: 30 December 2021

Number of pages: $345-363$

ISSN: 2679-3873

\section{Electronic reference}

Mireille Manga Edimo, "Expertise on the Anglophone Crisis in Cameroon: A Hybrid Cultural Boundary Approach", International Review of Public Policy [Online], 3.3 | 2021, Online since 30 December 2021, connection on 19 October 2022. URL: http://journals.openedition.org/irpp/2324 ; DOI: https://doi.org/ 10.4000/irpp.2324

\section{(c) (7)}

Creative Commons - Attribution 4.0 International - CC BY 4.0 https://creativecommons.org/licenses/by/4.0/ 


\section{Expertise on the Anglophone Crisis in Cameroon: A Hybrid Cultural Boundary Approach}

\section{Mireille Manga Edimo}

University of Yaoundé II, Cameroon

\section{Abstract}

How can we understand policy deadlocks and inactions embedded in the Anglophone crisis in Cameroon? The context sparked by corporatist demands of lawyers, teachers, and students in 2016 has included persistent rising numbers of killings, human rights issues, unending military battles, and contestations on multiple policy attempts to stop the crisis. The article looks at the Anglophone crisis as an issue of policy expertise. Policy expertise encompasses discursive practices that scan the crisis as a site of policy controversies producing deadlocks and inactions. It departs from critical policy studies towards expertise while considering the cultural context as a lens to observe and interpret expertise as a social relation. It, however, goes further, shoring up contestations and public distrust brought about by cultural differences and cultural knowledge. It places a stronger emphasis on the "historical context" to supplement the cultural context of expertise and encompass new cultural boundaries. The analysis stems from a critical postcolonial perspective, while introducing the 'hybrid' cultural contexts, 'hybrid' institutional designs, and 'virtual' discursive spaces which acknowledge the specific cultural character of a case study in the Global South. Using the interpretive methodology, the analysis has relied on documented history, policy discourses in different media, and interviews.

\section{Keywords}

expertise, experts, anglophone crisis, Cameroon, cultural boundaries, hybrid cultural context 


\section{Introduction}

Critical policy scholars have brought up the need to analyze social practices of expertise by conceiving expertise as a complex source of struggle over different meanings in different political communities. They have studied expertise by examining a range of cultural variables embedded in political structures and institutions. They have also questioned the 'dismissive snort, scare quotes, or recitation of failures' (Eyal, 2019), while bringing in 'public distrust' (Brown, 2013), rage and conflicts between the 'individual and institutions' (Durnová, 2019a; Durnová, 2019b), and social denials of environmental policies (Fischer, 2009). Most importantly, critical scholars have emphasized social crises coupled with loss in experts' legitimacy (Jasanoff, 2005; Cramer, 2016; Durnová, 2019a; Durnová, 2019b) while putting forward the role of cultural knowledge in the 'postmodern' (Fischer, 2005) and democratized world. All this scholarship means that the research agenda is now open to investigating the cultural politics of expertise. Such politics of expertise, while holding democratization as a normative claim (Strassheim 2016; 2017; Callon et al., 2011; Fischer, 2009), also presents a cultural challenge (Fischer, 2006; 2009).

This paper focuses on the cultural politics of expertise as a way of analyzing the hybrid cultural boundaries of expertise and puts forward the example of the Anglophone crisis in Cameroon. The Anglophone crisis is a socio-political crisis consisting of the termination of the State's federal nature in 1972 and the refusal to implement the country's decentralisation policy, leading to violent separatist actions. Rooted in the colonial heritage, the crisis has jeopardized the security and stability of the North-west and South-west regions. Integral to the present analysis and theoretical reflection are policy discourses centered around the position of Anglophone citizens in terms of Cameroon's socio-cultural, historical relations with the State or Cameroonian government. The cultural politics of expertise makes visible new deliberative social sites by combining a top-down constructed democratization process with reconstructed cultural knowledge, which emphasizes the importance of historical context.

Cultural politics of expertise can be understood through two major concepts relating to cultural boundaries of expertise. First, it highlights the hybrid nature of the cultural boundaries of expertise. The hybrid cultural approach connects expertise to the 'historical context' of an issue. It uses a 'dialectical approach' to expertise (Gil Eyal, 2019), acknowledging the role of history and the transformation of cultural contexts of expertise over time. By confronting the State's expert cultural knowledge with multiscalar cultural knowledge, the hybrid approach shows how expertise gets transformed through this confrontation. Such confrontation acknowledges, at the same time, that reception of cultural knowledge happens in a conflicting, interdependent, and complex cultural transnational environment. The analysis shows that the 'historical context' enables explanations of the 'societalization' (Alexander, 2018) of the expertise through a particular moment. Such societalization strengthens the role of expertise while fueling the crisis because it reinforces resistance to the expertise. The cultural politics of expertise re-centers the analysis of cultural interactions, 'inactions', and cultural resistances.

Second, expertise also moves outside the individual's, as well as regional and governmental institutions', hot-headed concerns about disclosing the Anglophone crisis in a transnational cultural context. Transnationalism is not new in policy studies. It has often examined learning practices, norms diffusion, and knowledge transfer in the Global South. It has nurtured the analysis of policy actions, administration, and public policies beyond the territorial boundaries of States (see Stone, 2004; Stone \& Moloney, 2019a; 2019b; 2020; Milhorance, 2018) while identifying multiple categories of 'knowledge agents' (Stone, 2012). The perspective in this paper is not dissimilar to such contributions. However, the paper supplements previous studies 
by establishing transnationalism as the consequence of the societalization of policy concerns and discourses on the Anglophone crisis in Cameroon and the historical-cultural context of democratic norms and values. The paper inaugurates the critical perspective towards expertise from the Global South, where the historical context adds to the cultural context at different levels.

In the specific case of Cameroon, members of government, 'local' civil societies, diplomats, international organizations, and non-governmental organizations operate as socio-cultural experts who strive to convince, advise, mediate, and devise solutions to the crisis. The policy discourses that they produce transcend the socio-cultural boundaries of the State of Cameroon. They reach out to transnational arenas, which transnational cultural experts acknowledge and promote through democratic-liberal technologies. Civil societies, owners of national newspapers, transnational media, social media, and the discursive possession of various information and communication technologies enhance the societalization of the expertise inside the management of this crisis. Through the analysis of policy discourses and narratives reported by the various public media, traditional private media, and social media in the cultural context of the Anglophone crisis - as well as by informal interviews and conversations with policymakers in the government, and by journalists, foreign diplomats, policy consultants, and religious authorities - the analysis displays the sociopolitical-cultural institutional 'micro' and 'macro' designs in which expertise takes place. The cultural politics of expertise highlights the variety of cultural knowledge while connecting the State's expertise to an interdependent, transnational cultural context. It also brings more profound arguments on history and the 'historical context' as part of the cultural politics of expertise.

\section{The Anglophone crisis in Cameroon}

Cameroon is a small country located in Sub-Saharan Africa, which inherited French and British cultures through colonization. It counts among the Sub-Saharan African political regimes characterized by relatively new democratization and regression towards authoritarianism following 15 years of the 'third wave' of democratization (Alexander, 2011, p. 53). The Cameroonian government has been challenged since October 2016 by the outbreak of the 'Anglophone crisis', defined as a crisis "in the country's termination of the federal nature of the State and the refusal to implement the decentralisation policy as agreed upon in the 20 January 1996, constitution" (INDJOURPD- 7092019).

Back in 1961, political elites from the former French-administered territory known as 'Eastern Cameroon' (representing four-fifths of the Cameroonian administration) and former Britishadministered territories known as 'Southern Cameroons' agreed on a one federal-state formation (Könings \& Nyamnjoh, 1997). The French-speaking dominating elites' cultures strived to build one 'unitary' state by extending French assimilationist policies to Anglophone regions. Citizens from these regions, commonly called 'Anglophones', considered these Cameroonian State's policies 'subversive' and 'marginalizing' in terms of their inherited British cultures (Crisis Group, 2017). They responded by creating Anglophone conferences and organizations which addressed their 'cultural frustrations' while using the liberal and political opportunities offered by the 'third wave' of democratization (Huntington, 1991) in Africa and the international diffusion of information and communication liberal technologies (ICTs) as early as the 1990s. Despite the introduction of more rights and liberal opportunities, the politico-cultural demands of the Anglophones concerning independence, return to federalism, autonomy, and separatism have brought no specific change concerning the State's methods. 
The Cameroonian government replied by obstinately denying an 'anglophoneness' (Jua \& Konings, 2004, p. 2; Ardener, 1967, p. 292; Crisis Group, 2019). The Cameroonian State radically rejected constitutional talks brought into the political agenda by the 1990s Anglophone claims and reignited since 2016 by Anglophone separatist movements. The experts of the Cameroonian State, through specific elites as well as through Francophone scholars, framed Anglophone claims as 'the mobilization efforts of a few discontented set of Anglophones who were denied a place at the dining table during political liberalization' (Sindjoun, 1995; Nkoum-Me-Ntseny, 1996; Menthong, 1998; Jua \& Konings, 2004, p. 3). Likewise, policymakers of the Francophone-dominant nation argued that "Anglophones have always received preferential treatment from the Cameroonian head of state" (P. Atanga Nji, 2016)1.

In the meantime, under 'societalized' socio-cultural and political pressure, the Cameroonian government created ad hoc committees to examine the crisis. These committees came up with technical solutions, such as equal promotion of the English and French languages, the Common Law, the creation of a National Commission for the Promotion of Bilingualism and Multiculturalism, and the recruitment of hundreds of Anglophones within the educational and law sectors, none of which, however, were able to solve the crisis. Various crises social sites were set up by the Cameroonian state's partners, as well as international organizations, transnational think tanks, the Cameroonian diaspora, and the media. They voiced concerns about human rights, military violence, arbitrary arrests, hostage-takings, lockdowns of the Anglophone regions, and an increase in the number of internally displaced persons (IDPs) and Cameroonian refugees across many countries, including Nigeria, Canada, and the United States of America (USA), and attempted in different ways to transform the State's cultural knowledge. The Cameroonian government acknowledged the organization of a 'major national dialogue' by extending its deliberative setting to party leaders, 'Anglophone' and 'Francophone' citizens of diverse professions and areas of activities, the Cameroonian diasporas, diplomats, members of non-governmental organizations, international economic partners, including banks and private and public companies, and religious and traditional leaders. Still, the deliberative setting and the designed solutions produced new criticisms and cultural struggles, as upholders of Anglophone separatist ideas abandoned commissions during deliberations.

The Anglophone crisis reveals the bounded cultural roles of the experts of the Cameroonian State. Expertise policy scholars have pointed out the lack of democracy, deliberation, and social participation in the policymaking process, using policy expertise. However, they have not offered an understanding of long-standing policy deadlocks such as that surrounding the Anglophone crisis. The answer lies in retrieving the complex and hybrid cultural contexts of expertise in the Anglophone crisis while using the perspective of critical policy studies on expertise and postcolonial theory on cultural hybridity. Whereas critical policy studies address the cultural policies of expertise as a characteristic of the postmodern world, 'cultural hybridity' contests a Western and liberal Cameroonian state's translation of experts' cultures, identities, and communities (see Busbridge, 2021; Bhabha, 1994). From a postcolonial state's cultural perspective, cultural hybridity puts the Cameroonian State's cultural knowledge in-between the standard, traditional and postmodern worlds. It illuminates ideologies embedded in the postcolonial State's political structures while clarifying the historical origins of particular social methods.

1 - Cameroon Tribune, 25 November 2016. 


\section{Material and Methods}

The following interdependent datasets have informed this analysis. We started by analyzing a selection of 100 newspaper articles published by national newspapers between September 2016 and December 2016, reporting different policy voices on the Anglophone crisis. This newspaper dataset includes political, public, academic, civil societies' and religious authorities' policy discourses on the Anglophone crisis and on how these actors framed the crisis as a policy problem. It encompasses four categories of public and private newspapers and political party journal policy voices, which played significant roles in the democratization process of the 1990s and which stand among the most known and read newspapers in the Cameroonian public sphere (see the attached appendices). In the attempt to understand how the Anglophone crisis was framed as a policy problem, the analysis of this dataset enabled us to identify the main categories of policy discourse on the crisis, the actors' profiles, and their historical relations with the crisis, the Cameroonian state, and the crisis dynamic. By considering the actors' choice of where to diffuse their policy discourses, the analysis also helped to locate the historical socio-cultural and ideological embeddedness of actors' policy discourses in the cultural context of the crisis. This dataset has clearly disclosed the democratization of expertise in the transnational cultural context of the Anglophone crisis. However, the analysis embraces neither the proposed governmental solutions to unravel the crisis, nor the alternative sociocultural policy discourses that uncover the post-2016 crisis period. To understand the policy deadlocks and inaction that followed this period, mainly characterized by the Cameroonian government's rounds of consultations with Anglophone civil societies, we analyzed the second round of media datasets and think-tank reports. These were further reinforced with interviewing and observing methods.

The second media dataset includes the online material posted on the crisis between October 2016 and 20 November 2021. It encompasses articles retrieved from Jeune Afrique Digital database, Global Factiva Dow Jones media database, Google trends, and Wikipedia websites. Whereas, from Wikipedia, we analyzed only one page summarizing significant trends of the crisis's policy discourses, Google trends served to identify the most heated periods of debates on the Anglophone crisis policy issue. It also helped to specify our data collection on the Jeune Afrique Digital and Global Factiva databases (see appendix 1. B). Jeune Afrique Digital and Global Factiva have been helpful for retrieving international policy discourses and various types of civil society policy voices unravelling the crisis and also cultural controversies. The think tanks' reports consist of six documents retrieved from the International Crisis Group website and one from the Vigie website (see Appendix 2 attached at the end of the paper).

In order to understand more fully, to contextualize, and to interpret the policy discourses' deadlocks, we complemented the previous analyses by interviewing national and foreign policy actors in actual situations so as to shed light on policy inactions embedded in actors' cultural behaviors. Toward that end, we took the opportunity of our immersed presence in diplomatic arenas where the Anglophone crisis's solutions were being negotiated, reformulated, and reconstructed by the various previously identified categories of policy actors. This regular presence allowed us to conduct ten (10) interviews, which we carried out as informal discussions and conversations within a framed period of more than three years (September 2017 to June 2021). All interviews took place in Yaoundé, Cameroon. The sample involved political authorities and personalities holding roles in managing the crisis. It included two members of government: one of French-speaking background, a political authority, and a former adviser to the Prime Minister's office, who also holds a top position in the ruling party and at the University 
of Yaoundé. It also comprised four foreign diplomats (one from France, one from the United States of America, one from the United Nations, and one from the European Union), one archbishop and one independent journalist (respectively spokesman and coordinator of the Anglophone General Conference between 2018 and 2019), one Anglophone lawyer and activist (co-founder of the Anglophone Civil Society Consortium), and two leaders of leading political parties from the opposition (the Cameroon Renaissance Movement and the Cameroon Party for National Reconciliation). Furthermore, our immersion in ten non-official diplomatic dinners, as with our relationships with some independent English-speaking Cameroonian elites, top-ranking government officials, religious authorities, other foreign diplomats, political party leaders, and many Cameroonian citizens of the diaspora, have kept us close to the topic.

The selected media articles, the think tank reports, observant-participation, informal discussions, and interviews were submitted to a 'configurational analysis' (Jackson, 2006, p. 266) of expertise. First, the 'ethnographic content analysis' (see Krippendorff, 2018, p. 22, 27; Yanow \& Schwartz-Shea, 2015, pp. 256-257; Jackson, 2015) of policy discourses retrieved from online media and national newspapers sought to identify policy actors and their historical sociocultural political structures. Second, it sought to retrieve policy discourses on how to unravel the Anglophone crisis. It looked at 'keywords in context' (Bauer, 2000), using MAXQDA 2018 and Python CAQDAS software. However, the ethnographic content analysis as a research method focused on sentences and arguments used by specific Anglophone policy actors. It aimed at contextualizing the understanding of the cultural politics of policy expertise. We then took that method further by examining the retrieved words, sentences, and arguments. The technique was used to track instances of policy actors' inaction and cultural resistance. We have also paid attention to social, political, institutional, and cultural knowledge, as suggested by configurational interpretive methods (see Yanow \& Schwartz-Shea, 2006, 2015; Jackson, 2006, 2015; Cefaï, 2013; 2020; Strassheim, 2019, 2020).

\section{The Cultural Politics of Expertise in the case of the Anglophone Crisis in Cameroon}

The cultural politics of expertise explores the social process through which socio-political relations, identities, norms, values, ideologies, and rules are contested, subverted, denied, rejected, "and possibly transformed" (Fischer, 2009, p. 249) in critical situations. It sees expertise as a radical failure to fix cultural knowledge beyond ideologies, social relations, norms, cultures, and historical experiences. It acknowledges transformation and complexity while rejecting the dichotomy between 'a seemingly apolitical sphere of knowledge and a politically loaded sphere of values' (Strassheim, 2017, p. 320). The cultural politics of expertise goes along with a 'no one-size-fits-all model of expertise' while disclosing variations over time, space, nations (Wagner et al. 1991; Strassheim, 2017, p. 329), and micro-sociocultural groups of individuals. It also brings territorial and social specificities through 'concrete' case studies and focuses on 'particular' societies. When applied to a particular political system, structure, or region, it puts forward institutional and social logics as cultural singularities, methods, specific mannerisms, phantasmagorias, and inactions while explaining and clarifying the cultural variables toward policy deadlocks. This paper supplements the concept by emphasizing cultural dichotomies beyond the national cultural boundaries of States. We acknowledge structural interdependencies between cultural experts while confronting the boundaries of their socio-cultural political structures through policy discourses. Our perspective puts forward micro-agent and macroagent structures as cultural entities while bringing in their socio-cultural and political relations with the State's expertise. 
Expertise refers to 'social relations' (see Fischer et al., 2017; Strassheim, 2017), displaying the various manners through which different socio-cultural and political actors interact to produce policy solutions. It is the lens through which actors are explicitly involved in the political process of knowledge production in a particular crisis, or in the policymaking process, and how they are involved. Expertise enables us to 'know that there are actual actors involved (in the policymaking process): the experts' (Eyal, 2010, p. 3) by answering the questions 'who is talking? To whom? (How?) And why (solutions)?'. It is similar but not limited to 'policy discourse' (Eyal, 2010, p.3). Expertise puts forward experts' socio-cultural relations through their practices and activities while acknowledging a 'historical approach' of its contextual usage (Eyal, 2019, p. 14) or historical 'contextualization' (Strassheim, 2017, p. 321). The debate is neither about the 'expertness' of experts, nor about the materiality of their activities (see Eyal, 2019, p. 15, 19). Expertise relates to socio-historically anchored cultural practices that delineate political spaces, the social sites of experts' activities, and related methods. Expertise is unquestionably a relational cultural activity involving traditional and modern institutions, modern and postmodern ideologies and values, individuals and their micro-macro-social and institutional-cultural sites. The contextual meaning of expertise cuts across simple specificities such as 'ways of talking' (Eyal, 2019, p. 19-20), or 'ways of doing', attributed to one specific category or group of individuals, professions, politicians, or 'particular' institutions. Expertise acknowledges these various forms of practices across socio-cultural groups' activities while confronting the State's methods, cultures, policy outputs, and 'inactions' to a socio-cultural relational context, where socio-cultural and political actors struggle and interact to impose their 'cultural knowledge' (Fischer, 2009).

Critical policy scholars examined these experts' struggles and cultural interactions within the State's national boundaries. On the one hand, they focused on individual emotional practices (Durnovà, 2019a; 2019b). On the other hand, they also put forward reimagined, reinvented, and reconstructed deliberative/discursive spaces within a postmodern world context of identities (see Fischer, 2009). The historical-cultural context of the Anglophone crisis takes these boundaries further by acknowledging transnational communications across different types of cultural, national, and international boundaries: regime type, the State's cultures, methods and traditions, the international political environment, national and international institutions, and postmodern cultures. The complexity acknowledged by these transnational, interdependent historical and socio-cultural variables suggests using a more complex model of cultural politics. The hybrid cultural model would buy conflict in experts' socio-cultural relations while putting forward their cultural interactions beyond the national cultural state's boundaries in the interdependent historical context of the Anglophone crisis.

In the cultural context of the Anglophone crisis, transnational experts' policy discourses are brought in by various socio-cultural and structural factors, including historical context, historical relations, and historical experience through ideas on democracy and democratization. Their activities acknowledge complexity through the plurality and transnationalisation of their policy discourses in an interdependent historical and socio-cultural context of experts' discourses and cultural relations. At the same time, this context acknowledges a dialectical cultural context where experts are both needed and rejected (Eyal, 2019) 'in between' a modern and a postmodern world.

The hybrid cultural model retrieves and explains the historical-cultural context of expertise on the Anglophone crisis by bringing in confrontations between various cultural boundaries. In contrast with previous cultural explanations of expertise, the hybrid cultural model pays atten- 
tion to experts' diverse cultural and historical locations while bringing them into reinvented and reimagined micro- and macro-socio-cultural deliberative sites. It confronts religious, traditional, diplomatic, and transnational experts' cultural knowledge with the State's cultural practice. The hybrid cultural model displays both reception and rejection of provided cultural knowledge. In this view, the Anglophone crisis is shaped by the democratization of liberal technologies, transnational means of communication, international cooperation, diplomacy, advocacy, and international cultural norms, values, and ideologies challenging traditional postcolonial practices.

The historical context connects with political expertise's embeddedness character (Strassheim, 2017, p. 329). However, the Anglophone crisis takes it further by alleging communications between various historical locations of expertise, cultures, and their local, transnational, and international relational voices. It also displays the changing cultural interactions over policy issues, time, and cultural boundaries while bringing in confrontations between local/national/ (transnational) cultures (see Jasanoff, 2011a; Strassheim, 2017). It explains conflicting cultural interactions on the framing of democracy/democratization, how these interact, and the 'demographic changes and technology' (Durnovà, 2019, p. 3). Additionnally, these variables are drivers for transforming the Cameroonian State's expertise, which operates an 'in-between' (Levitt, 2002) confrontational cultural life that relies on States' hybrid format of policy outputs.

In his study of Kerala, a small State in India, Frank Fischer put forward the 'deliberative space' (Fischer, 2009, p. 247) as the institutional design through which to include the role of a broader spectrum of citizens, politicians, and experts in the pursuit of policy decisions (Fischer \& Boossabong, 2018) and to understand the shifts from politics to culture, social meanings, and identity politics in a postmodern world (Fischer, 2009, p. 247). A closer look at such institutional design, done by both authors, puts forward the creative, invented, constructed cultural character of struggles with a technocratic and largely anti-democratic bias (Fischer \& Boossabong, 2018) while democratizing the setting. However, we supplement the institutional design by emphasizing multiscalar alternative discursive spaces, social sites, public spheres, and policy discourses that encompass both micro-cultural structures of Cameroonian political life and macro-cultural and political structures of the decision-making process. These structures engage collective and individual actors and political institutions at different levels of cultural interaction. They feature an identity policy struggle confronting a plurality of historical structural agents. However, there are no procedural types of interaction as these would disclose a deliberative setting. Cultural discursive interactions are both authoritative and anarchical. They simply mean putting concepts within their historical contexts while broadening explanations of a particular socio-cultural and political reality. Likewise, historically contextualized concepts better convey politically embedded cultural facts such as democratization and expertise. Whereas, in previous scholarship in critical policy studies, democracy operates as a set of normative claims that have a bearing on empowerment, participation, deliberation, and inclusion (Fischer, 2009; Fischer et al. 2017; Strassheim, 2017; Callon et al. 2011) in socio-cultural contexts of citizens' empowerment, in the historical context of the Anglophone crisis, democracy relates to multi-polarization, pluralization, densification, and enlargement of the public sphere while bringing in an assortment of both conflicting and interrelated cultural knowledge with different socio-cultural backgrounds. While including standard political institutions in the analysis, expertise on the Anglophone crisis discloses discursive spaces not as 'deliberative spaces' per se (see Fischer, 2009; 2006; Fischer \& Boossabong, 2018), but as alternative reimagined and constructed alternative deliberative social sites taking advantage of the commu- 
nalization of cultural interest to stop the crisis. This being acknowledged, the hybrid model of the cultural context of expertise politics inserts both hybrid institutional designs of expertise and hybrid deliberative social sites involving State experts of different cultural backgrounds. However, their cultural knowledge confronts the dominant State's cultural knowledge in the expertise policymaking process of designing crisis solutions.

\section{Multiscalar Experts' Social sites and the Transformation of the State's Expertise Cultural Boundaries}

Policy expertise in the particular cultural context of the Anglophone crisis in Cameroon highlights who gets in the talks? Where? And how? These questions are the critical tools for retrieving the hybrid cultural character of expertise in the Anglophone crisis in Cameroon. The section identifies formal and informal deliberative settings embodied in governmental and nongovernmental political-cultural institutional practices and activities toward expertise in the Cameroonian context of the Anglophone crisis. It simultaneously puts forward the boundaries between them by bringing in the different types of cultural knowledge and their roles in the context of the crisis. It further concludes by drawing the implications for the expertise policymaking process in the Cameroonian context of the Anglophone crisis.

\section{The formal and informal Cameroonian State's deliberative settings and methods}

The formal and informal Cameroonian deliberative settings in the Anglophone crisis delineate the State's expertise by referring to its cultural-institutional social sites embodied in the State's agents and their roles and activities in the Anglophone crisis. The Cameroonian State's agents include current and former government members, ministers, administrative officials, politicians, academics, and a few members of civil society. The State's agents deliberate through ad hoc committees, commissions, inter-ministerial meetings, and meetings with civil society organizations. They make up the State's public social sites at ministerial and regional levels (Anglophone regions).

Two ad hoc committees were established to unravel solutions to the crisis. These ad hoc committees worked under the authority of the Cameroonian Prime Minister. At the same time, the Prime Minister's Director of the Cabinet (an academic and a professor of science at the University of Yaoundé) chaired the Committee tasked "with examining and proposing solutions to the concerns raised by Anglophone teachers' trade unions (...); and discuss(ing) the conditions for implementing solutions adopted" (Cameroon Tribune, 20 February 2019). The Minister Delegate to the Minister of Justice chaired the other committee, tasked with "proffering solutions to grievances of Common Law lawyers" (Cameroon Tribune, 20 February 2019). Both the Anglophone and Francophone State's agents participated in these formal deliberative settings.

Deliberations in these State social sites included inter-ministerial talks with Anglophone civil societies. In Anglophone regions, they involved contacts with traditional, religious, and party leaders and Anglophone civil society organizations.

Further, in these two types of deliberative settings, the State's agents framed Anglophone demands around trade unions' 'technical' demands. However, the devised solutions, methods, and practices faced the Cameroon Anglophone Civil Society Consortium (CACSC) and Southern Cameroons National Council (SCNC) federalist policy discourses. The leaders of these organizations boycotted the State's ad hoc committees and referred to them as "so-called" committees (Concord News, 17 January 2017). In addition, Anglophone leaders contesting the structure of 
Committees put in place by the State were arrested and banished from Cameroon's territory. ${ }^{2}$ In parallel, the ad hoc committees had to deal with media comments. Unlike the public declarations that the committees were "broad-based" and the reports on the State's 'crusades' aimed at ending the crisis (Cameroon Tribune, 20 February 2019), the ad hoc committees faced the criticisms of the Anglophone media (see Concord News, 17 January 2017).

Another formal deliberative social site is the National Commission for Bilingualism and Multiculturalism (NCPBM). NCPBM was created in 2017 to carry out an advisory role within the State. It is led by the former Cameroonian Prime Minister, Peter Mafany Musonge, an influential CPDM Anglophone Senator in the Cameroonian Parliament. He leads the NCPBM with State agents carrying out administrative functions at the Ministry of Education and performing roles in CPDM, the State's party. The NCPBM counts 'thirteen members of the civil society' (Cameroon Tribune 17 March 2017), including one Catholic Church authority and four English-speaking Cameroonian citizens. As with the ad hoc committees, the Cameroonian state's agents dominate the NCPBM through experts' administrative functions and roles in the State's party (see the NCPBM website). ${ }^{3}$ Again, as with the ad hoc committees, the NCPBM underwent Anglophone media criticism for being virtually present (Concord News, 21 September 2017), adding to an upsurge in hate speech in the Anglophone regions.

The formal state's committees' activities coincided with tensions regarding "a Cameroonian State doing nothing" (Africa report, 26 September 2019) and needing to refresh its politicalcultural leadership to unravel the crisis. On 4 January 2019, President Paul Biya, the Cameroonian Head of State, appointed a new Prime Minister. In contrast to the former Prime Minister, Philemon Yang, the new Premier, Joseph Dion Ngute, was entrusted with the political and cultural task of 'bringing back peace' in the regions by accelerating the "dialogue" (Africa report, 26 September 2019). Joseph Dion Ngute was Minister delegate in charge of relations with the Commonwealth between 1997 and 2018 and in charge of relations with the presidency until he was appointed Prime Minister in January 2019. He is also known as a member of a family of top-ranking officials in the English-speaking South-West region, a long-standing member of CPDM (the ruling party), and a traditional ruler who shaped the Cameroonian State's cultural interactions on expertise.

Negotiations, dialogues, and formal and informal micro-macro deliberative, institutional, faceto-face methods came into force. Joseph Dion Ngute intensified his visits to the two Anglophone regions. He met, and held discussions with, traditional rulers with whom he held the South-West Chiefs conference in the South-west region, one of the Anglophone regions. He also met, and held discussions with, political leaders from the North-West, the other Anglophone region. These included Ni John Fru Ndi, a traditional ruler and political leader of the Social Democratic Front (SDF) party which had championed democratization in the 1990s.

These transformations of expertise, characterized by macro-micro interactions at the institutional State levels and at regional social levels, included meetings between the State's institutions and socio-cultural actors of the Anglophone societies. However, they extended to other regions, such as Yaoundé, where diplomats and civil actors reinvented new deliberative social sites. These sites included diplomatic, religious, political, and civil societies' cultural knowledge (detailed in the Crisis Group report, 2019, $\mathrm{n}^{\circ} 272$ ).

2 - For instance, the CACSC was banished through a State's decree on 18 January 2017.

3 - https://www.ncpbm.cm/en/commission/members. 


\section{Transnational deliberative settings and methods}

Transnational deliberative settings intervened in the above cultural context of the Cameroonian state's policy expertise by adding the contribution of diplomatic and international policy discourses to media comments on the crisis. These diplomatic and international policy voices included the European Union (France, Germany, and the UK), the United States of America (USA), Switzerland, the Vatican (Roman Catholic Church), and the United Nations (UN). The sections below describe these institutional transformations of policy expertise by putting forward the Cameroonian policy expertise's modern, 'postmodern', and hybrid social sites and methods.

Transnational deliberative settings emerged within the context of antagonistic and multidirectional policy discourses dividing international actors, the Cameroonian State's agents and their institutions, Anglophone civil societies, and transnational think tanks. They put forward new experts' roles, activities, and methods confronting the Cameroonian government. They indicated that the Cameroonian government was facing Anglophone separatists voicing international mediation (through the U.N., the African Union (A.U.) or the U.S. government). They also put forward that the Cameroonian military forces were facing accusations from Human Rights Watch (HRW) and Amnesty International, and that the think tank, International Crisis Group, was calling for international intervention and mediation.

Transnational deliberative settings managed to reconcile international policy voices: the U.S. ambassadors and the State's agents, voicing threats of sanctions and interventions; the UN, through the UN Secretary-General, voicing warnings about security issues and dangers to international peace and stability; the U.K. being focused on humanitarian impacts and aid; Canada and Switzerland striving to offer international expertise; and the Islamic Bank concentrating on economic issues. They sought to transform such heated policy discourses being set against the Cameroonian government and its methods. They also looked to transform the Cameroonian State's "denials, disdain and violence" (ICG, 2019, p. 11) into dialogue and action.

In this context, France, Cameroon's historical-cultural partner since the colonization period, showed a concern to transform the Anglophone crisis situation. The USA convened meetings with civil society leaders, taking in religious leaders such as Cardinal Tumi (a Catholic archbishop), Anglophone separatist leaders such as Agbor Talla, and government representatives. ${ }^{4}$ French diplomats and ambassadors engaged in discussions and negotiations with various conflicting policy actors regarding the Anglophone crisis. These actors included members of the Anglophone civil society and religious actors, except think tanks, Switzerland, and Canada. Through talks and negotiations, French diplomats in Yaoundé, with the support of the European Union (EU), held many formal and informal meetings with the Cameroonian State's agents in top-level bureaucracy and civil society.

These French talks happened following public and private meetings with Cameroonian actors. They brought in various local and international policy actors. In parallel, they created diplomatic negotiations at both the top level (the Cameroonian administration) and the bottom level (Cameroonian society) while involving the Cameroonian State's experts and civil society organizations. The French diplomatic methods held talks between the above micro-state agents while engaging with religious and Anglophone civil society elites. They created cultural interactions and deliberations beyond individual, socio-cultural, and State boundaries in two specific ways.

4 - https://www.henriettethatchers.com/2018/04/us-ambassador-to-cameroon-peter-henry.html. 
First, French informal and private meetings happened through private dinners. They put forward cordial and friendly cultural interactions between Cameroonian Anglophone civil society leaders, party officials, technocrats, academics, journalists, and parliamentarians, who met with other partners of the Cameroonian and French States, such as the EU, Spain, the U.S.A., United Nations, and other diplomatic officials. These meetings produced discussions and informal deliberations among formerly opposed actors.

The French talks in Yaoundé, which included US diplomats, UN, EU, and Spanish diplomatic representatives, religious and traditional actors, and Anglophone civil society leaders, were aimed at stopping the crisis through recognizing mutual interests. They looked to rediscover diplomatic, transnational cultural knowledge and deliberative social sites centered around organizing "strategically" and collectively in order to terminate the Anglophone crisis. In contrast to the ad hoc committees and the State's commissions, similar meetings with the same cultural configurations were often repeated. Deliberations evolved through interpersonal and face-toface discussions. Policy agents in these settings often met following the reimagined French diplomatic social sites and methods. They talked as friends, partners, and associates while jointly acknowledging the necessity "to do something" (USDIPD-14062019; ARCH-14062019; INDJOURPD- 7092019).

There were also formal top-level meetings where foreign diplomats, from the U.S.A., France, Canada, and Switzerland in particular, met the Cameroonian Head of State or the new prime Minister, Joseph Dion Ngute. In this case, diplomatic officials (from France and elsewhere) addressed the policy issues around the Anglophone crisis in both formal and informal political conversations. Diplomats sought to convince the Cameroonian state to talk in these deliberative settings.

Through various forms, transnational deliberative settings have put forward mutual interests to "restore and reinforce democratization while bringing peace and stability back in the region" (USDIPD-14062019; UNDIPD-14062019; UEDIPD-14062019). Transnational deliberative methods transformed policy expertise by intensifying cultural interactions at different Cameroonian State and society levels.

Negotiations came into force as the other side of the informal and formal talks carried out by French diplomats. Negotiations included 'reimagined' and 'reinvented' diplomatic practices and activities that brought together Anglophone civil society with religious and traditional voices. The negotiations also included arguments related to the future of Cameroonian politics. Through negotiations and talks, the divided UN, French and U.S.A. diplomats reframed their knowledge about the crisis while agreeing on the need for democratization as a shared cultural position. In the meantime, negotiations introduced Anglophone civil societies in deliberative settings through religious and chieftaincy voices (traditional authorities) while also including Cameroonian political elites' voices.

Transnational think tanks, such as the International Crisis Group (ICG), also played influential roles in these transnational cultural configurations. They advertised the clashes between the Anglophone separatists and the Cameroonian governments. They also put forward facts showing evidence of the necessity of carrying out international action. In addition, International Crisis Group (ICG) used its legitimacy to report on human rights issues and threats to international peace and stability, reinforced by UN, EU, and UK policy discourses on the Anglophone crisis. 


\begin{abstract}
"The conflict in the Anglophone regions of Cameroon is deadlocked. There is no dialogue between Yaoundé and the separatists, who (refuse) to give ground: the government is counting on a military victory and refuses to discuss the form of the state; the separatists demand independence.

(...) Both (Anglophone separatists and the Cameroonian government) must explore compromise solutions aimed at a level of regional autonomy somewhere between the secession the separatists yearn for and the fake decentralization proposed by Yaoundé" (ICG, May 2, 2019).
\end{abstract}

Similarly, liberal-democratic tools such as online newspapers, journals and virtual social sites, including Facebook, Twitter and WhatsApp, helped to render the crisis more visible. They conveyed controversial policy discourses while putting forward the 'particular' discourses of Anglophone civil societies, party leaders, religious actors, foreign governments, and international and regional organizations. These specific roles were undertaken by various websites, including: online journals and newspapers such as Jeune Afrique, All Africa Report, JournalduCameroun. com, and Concord News; foreign governments' websites, such as the US State Department website; French media, such as Le Point Afrique, RFI, Africa.24; NGOs and think tanks, such as Human Rights Watch (HRW) and the ICG; and virtual social sites involving personal blogs, specific Facebook pages, Twitter accounts, and WhatsApp groups carrying debate or comments on the crisis. While reinventing postmodern virtual social sites, these liberal-democratic technologies emphasized discursive interaction between the Cameroonian government's practices and methods, Anglophone separatists/federalists, and religious and foreign discourses by reporting States' ongoing practices and activities around the crisis and alternative policy discourses.

For instance, on 23 May 2018, Jeune Afrique reported: "U.S. ambassador summoned after criticizing the management of the Anglophone crisis" (see Jeune Afrique, 23 May 2018). In April 2018, henriette.thatchers.com ${ }^{5}$ posted pictures and reported: "US Ambassador to Cameroon Peter Henry Barlerin (was looking) for solutions to the Anglophone Crisis" along with the religious actor, "Emeritus Cardinal Tumi", and the Anglophone activist and separatist, "Barrister Agbor Balla", as well as host of others including a government representative. On 5 November 2020, Human Rights Watch (HRW) reported through its website: "The US cuts Cam-

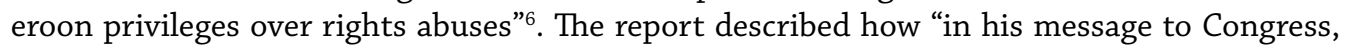
President Trump said Cameroon has failed to address concerns regarding government forces' persistent human rights violations, including extra-judicial killings, arbitrary and unlawful detention, and torture" (HRW website, 5 November 2019). In this way, while reinforcing the societalization of the crisis, liberal democratic technologies put forward (transnational) virtual deliberative social sites. These virtual social sites operate beyond the territories and boundaries of modern states while disclosing cultural interactions within different levels of experts' socio-cultural relations. They connected to national and international policy discourses on the Anglophone crisis while bringing in human rights discourses, as well as democracy, independence, autonomy, federalism, and separatism as the conflicting policy discourses confronting the Cameroonian State's methods.

The discourses of Anglophone civil societies and religious and transnational think tanks met with the legitimate and international support of organizations such as the UN and the EU and States such as the USA and the Vatican (Roman Catholic Church). Yet, they encountered deadlock when meeting the head of the Cameroonian State's policy discourse. In contrast to the UN,

5 - https://www.henriettethatchers.com/2018/04/us-ambassador-to-cameroon-peter-henry.html

6 - https://www.hrw.org/news/2019/11/05/us-cuts-cameroon-trade-privileges-over-rights-abuses 
EU, and the USA, which put the Anglophone crisis on their political agenda, the Cameroonian State rejected it in 2018 and 2019 through the Head of State's voice of the Anglophone General Conference (AGC) proposed by Cameroonian religious organizations including Muslims, Catholics, and Protestants led by the Catholic archbishop, Christian Cardinal Tumi (ICG report, 25 April 2018).

Furthermore, the UN Security Council set up a meeting at the request of the USA by citing an "emergency humanitarian crisis" in May 2019. One month later, the EU Council deliberated on the crisis. It framed acts of extra-judicial execution by the Cameroonian government's military forces in Anglophone regions (Jeune Afrique, 13 May 2019). The Secretary of the UN Human Rights Commission organized a special visit to Cameroon in May 2019, where she talked with the Head of State. ${ }^{7}$ The international organization La Francophonie released a statement in October 2017 and Canada and Switzerland proposed international expertise based on their experience of historical-cultural multiculturalism (see Jeune Afrique, 28 June 2019 and 29 July 2019).

Transnational policy discourses convey the "necessity to act" in order to provoke "dialogue" and an "international solidarity" against the Cameroonian State's expertise and methods. These various micro- and macro-socio-cultural experts' activities and relations reflect the hybrid-cultural character of policy expertise on the Anglophone crisis in transnational deliberative social sites. The policy discourses of transnational media, Anglophone civil societies, and think tanks policy reveal the postmodern locations and nature of discourses on 'human rights', 'independence', 'freedom', 'separatism', 'federalism', and 'regionalism'. Likewise, institutional-regional social sites (the EU, for instance) and international policy discourses within, across, and 'in between' the boundaries of the Cameroonian State and its international partners' deliberative settings reinforced this hybrid cultural character.

\section{The Major 'National' Dialogue Deliberative Setting}

On September 10, 2019, Paul Biya, the Cameroonian head of state, convened a 'major national dialogue' through a televised speech after intensified diplomatic talks at national and transnational levels, including rounds of political consultations carried out by Prime Minister Joseph Dion Ngute and French diplomats. Yet President Paul Biya framed the dialogue within the boundary of the 1996 Cameroonian constitution ${ }^{8}$ by rejecting the ideas on separatism and federalism of the Anglophone separatists.

Compared with the other ad hoc committees and commissions of the Cameroonian state, the 'national dialogue' brought eight commissions. These were chaired by the Prime Minister, Joseph Dion Ngute. From 30 September to 4 October 2019, they took place at the Cameroonian Congress Palace in Yaoundé while bringing in various forms of cultural knowledge, including Anglophone civil societies. As with the transnational deliberative settings, these commissions brought together Cameroonian political leaders, government members, CPDM members, religious and traditional actors, academics, and economic entrepreneurs from Francophone and Anglophone backgrounds. They also included more members from the Cameroonian diaspora and from Anglophone civil society. Yet the State's administrative and political cultures dominated the commissions. Actors from the CPDM, the dominant ruling party, were the most numerous group. Anglophone citizens and elites from the Anglophone Cameroonian diaspora

7 - https://www.prc.cm/en/news/audiences/3468-president-biya-holds-talks-with-un-high-commissioner-for-human-rights

8 - https://www.prc.cm/en/news/3779-nord-ouest-sud-ouest-paul-biya-convoque-un-grand-dialogue-national-eng 
headed commissions linked to technical aspects of the regional crisis, such as 'the educational system', 'the judiciary system', and 'reconstruction and development of affected regions'. Religious actors headed one commission on the 'return of displaced persons'. In contrast, the State's political actors led the most decisive commission, on 'decentralization' (see Table 1)

Table 1: Leading micro socio-cultural political structures in the 'major national dialogue'

\begin{tabular}{|c|c|c|}
\hline Commissions & President & Vice-presidents \\
\hline \multirow[t]{3}{*}{$\begin{array}{l}\text { Bilingualism and } \\
\text { cultural diversity }\end{array}$} & $\begin{array}{l}\text { An Anglophone, President of So- } \\
\text { cial Democratic Front (opposition } \\
\text { party) }\end{array}$ & $\begin{array}{l}\text { - Two former members of the gov- } \\
\text { ernment, both members of the } \\
\text { central committee of the ruling } \\
\text { (CPDM) party }\end{array}$ \\
\hline & $\begin{array}{l}\text { Represented at the National As- } \\
\text { sembly }\end{array}$ & $\begin{array}{l}\text { - one traditional ruler (South-re- } \\
\text { gion) }\end{array}$ \\
\hline & & $\begin{array}{l}\text { - one retired p xrofessor of history, } \\
\text { member of the ruling party }\end{array}$ \\
\hline \multirow[t]{4}{*}{$\begin{array}{l}\text { Educational } \\
\text { system }\end{array}$} & $\begin{array}{l}\text { Anglophone (a woman) Former } \\
\text { Vice-chancellor of the University } \\
\text { of Buea, former Minister of educa- } \\
\text { tion, member of the political bu- } \\
\text { reau of the ruling party }\end{array}$ & $\begin{array}{l}\text { - Director of Cabinet at the Prime } \\
\text { Minister's office; Chair of one of } \\
\text { the ad hoc committees. }\end{array}$ \\
\hline & & $\begin{array}{l}\text { - one historian, international con- } \\
\text { sultant, a former member of the } \\
\text { Cameroon parliament (1988-1992) }\end{array}$ \\
\hline & & - one politician (female parliament) \\
\hline & & $\begin{array}{l}\text { - one professor, board member } \\
\text { chair of the GCE Board, Cameroon } \\
\text { ministry of education. }\end{array}$ \\
\hline \multirow[t]{5}{*}{ Judiciary system } & $\begin{array}{l}\text { Member of the National Com- } \\
\text { mission for the Promotion of Bi- } \\
\text { lingualism and Multiculturalism } \\
\text { (NCPBM) }\end{array}$ & $\begin{array}{l}\text { - one lawyer, chair of the Cameroon } \\
\text { Lawyers' Council since }\end{array}$ \\
\hline & $\begin{array}{l}\text { Held various functions within the } \\
\text { Cameroonian government }\end{array}$ & $\begin{array}{l}\text { - one lawyer, magistrate by profes- } \\
\text { sion; former Minister of justice }\end{array}$ \\
\hline & & $\begin{array}{l}\text { - one former SDF leader and Vice } \\
\text { president of the National Assembly }\end{array}$ \\
\hline & & - CPDM member, political scientist \\
\hline & & - one member from the civil society \\
\hline
\end{tabular}




\begin{tabular}{|c|c|c|}
\hline \multirow[t]{5}{*}{$\begin{array}{l}\text { Decentralization } \\
\text { and development }\end{array}$} & $\begin{array}{l}\text { Politician, former Cameroonian } \\
\text { Minister (2011-2018) }\end{array}$ & $\begin{array}{l}\text { - one professor of law, working at } \\
\text { the Prime Minister's office, mem- } \\
\text { ber of the CPDM, member of the } \\
\text { 'political bureau' of the 'major na- } \\
\text { tional dialogue.' }\end{array}$ \\
\hline & CPDM member & $\begin{array}{l}\text { - one CPDM senator, city mayor in } \\
\text { the South-west region }\end{array}$ \\
\hline & & $\begin{array}{l}\text { - one former governor of the North- } \\
\text { west region, member of the CPDM }\end{array}$ \\
\hline & & - one senator, UNDP (opposition) \\
\hline & & $\begin{array}{l}\text { - one professor of public law, mem- } \\
\text { ber of the Constitutional Council... }\end{array}$ \\
\hline \multirow[t]{6}{*}{$\begin{array}{l}\text { Reconstruction } \\
\text { and development } \\
\text { of affected } \\
\text { regions }\end{array}$} & $\begin{array}{l}\text { Senior Associate for Africa and } \\
\text { Regional Director at the National } \\
\text { Democratic Institute for Interna- } \\
\text { tional Affairs, human rights advo- } \\
\text { cate }\end{array}$ & $\begin{array}{l}\text { - one woman, rector at the Uni- } \\
\text { versity of Ngaoundéré (one of the } \\
\text { French regions) }\end{array}$ \\
\hline & $\begin{array}{l}\text { (Member of the Cameroonian dias- } \\
\text { pora) }\end{array}$ & $\begin{array}{l}\text { - the president of the Cameroon- } \\
\text { inter-employer group. }\end{array}$ \\
\hline & & $\begin{array}{l}\text { - one from the SDF party (opposi- } \\
\text { tion) }\end{array}$ \\
\hline & & $\begin{array}{l}\text { - one from the Progressist move- } \\
\text { ment (opposition) }\end{array}$ \\
\hline & & - one from the NCPBM. \\
\hline & & $\begin{array}{l}\text { - one government administrative } \\
\text { (ministry of livestock, fisheries and } \\
\text { animal industries) }\end{array}$ \\
\hline \multirow[t]{3}{*}{$\begin{array}{l}\text { Return of } \\
\text { displaced persons }\end{array}$} & $\begin{array}{l}\text { Religious authority (Cardinal, } \\
\text { Catholic Church) }\end{array}$ & $\begin{array}{l}\text { - one human rights policy adviser, } \\
\text { former UN representative for Cote } \\
\text { d'Ivoire (from the Cameroonian di- } \\
\text { aspora) }\end{array}$ \\
\hline & & $\begin{array}{l}\text { - one former Minister, member of } \\
\text { the ruling CPDM party, }\end{array}$ \\
\hline & & $\begin{array}{l}\text { - one leader of the PCRN party (op- } \\
\text { position) }\end{array}$ \\
\hline \multirow[t]{3}{*}{$\begin{array}{l}\text { Disarmament } \\
\text { and } \\
\text { demobilization }\end{array}$} & $\begin{array}{l}\text { A historian, university professor, } \\
\text { dean of the faculty of arts at the } \\
\text { University of Maroua. }\end{array}$ & - mayor, parliamentarian. \\
\hline & & - one from the diaspora. \\
\hline & & $\begin{array}{l}\text { - one former South-west governor, } \\
\text { politician, CPDM member. }\end{array}$ \\
\hline
\end{tabular}




\begin{tabular}{|l|l|l|}
\hline $\begin{array}{l}\text { The role of } \\
\text { diasporas }\end{array}$ & $\begin{array}{l}\text { Professor of Public law, former Di- } \\
\text { rector of the cabinet of the Secre- } \\
\text { tary-general of the international } \\
\text { organization of 'La Francophonie' }\end{array}$ & $\begin{array}{l}\text { - one from a public policy think } \\
\text { tank. }\end{array}$ \\
\hline & $\begin{array}{l}\text { - one UN journalist, based in the } \\
\text { USA. }\end{array}$ \\
\hline & $\begin{array}{l}\text { - one writer based in France, Cam- } \\
\text { eroonian cultural ambassador. }\end{array}$ \\
\hline & $\begin{array}{l}\text { - one doctor, based in France. } \\
\text { - one from the International Mon- } \\
\text { etary Fund (IMF), based in Wash- } \\
\text { ington, USA... }\end{array}$ \\
\hline
\end{tabular}

Source: The Author

The above data reveal that the 'major national dialogue' enlarged the State's deliberative setting. They also show the contribution of the ruling party ideology (the CPDM) in the established commissions.

Needless to say, this pluralist character of the 'major national dialogue' setting failed to clear up the cultural tensions between the Anglophone federalists and separatists. The 'national' dialogue put forward conflicting policy discourses between the Anglophone federalist voices and the Cameroonian government. Whereas the government rejected all kinds of solutions linked to the Cameroonian 'form of state', the Anglophone separatists once again boycotted the dialogue brought forward by the Cameroonian government. Anglophone separatists criticized the 'rubbish' character of the State's policy on decentralization (Agbor Balla, JournalduCameroon. com, 21 January 2020). They also claimed a new 'national dialogue' on a 'new basis' (Akere Muna, Jeune Afrique, 2 November 2019) by including Anglophone party and federalist voices such as NOW, chaired by Akere Muna, an Anglophone lawyer, and Agbor Balla, a co-founder of the CACSC.

The above picture of the crisis illustrates how transnational actors, such as the Anglophone civil society and party leaders, communicated their specific views on unravelling the crisis. They show the various forms taken by their cultural interactions with the State's methods and the persistent cultural character of the State's experts' activities, practices and policy discourses. It also reveals more about the moves from radical positions to more radical positions and vice versa.

The various historical contexts result in these policy discourses becoming either pending, legitimate, or simply dominant in the debate. In addition, the plurality of historical contexts put forward in the picture of the crisis' given above unveils various forms of deliberative and discursive settings while displaying the transformation of the Anglophone crisis through policy expertise. The crisis, which becomes an interdependent structural situation, discloses the production of both policy arguments and radical positions, as well as the role of modern (traditional/physical) political sites coupled with postmodern (virtual social sites such as Facebook, Twitter, online media, newspapers, etc.) and 'reinvented' social sites where actors agree, disagree, and negotiate on the basis of their mutual interests in the crisis. 
The hybrid cultural context of expertise puts forward multiscalar levels of deliberation toward the Anglophone crisis in Cameroon. However, compared with postmodern institutional deliberative 'designs', deliberation confronts and introduces interactions between various social sites involving experts' talks, negotiations, and cultural interactions. Such talks, negotiations, and cultural interactions, amid the search for solutions to end the Anglophone crisis, have portrayed multiscalar and multidimensional cultural confrontations between, on the one hand, the State's methods, 'inactions', resistance, and ways of doing and, on the other hand, Anglophone civil societies' and the State's international partners' policy discourses. These various forms of multilevel cultural confrontations between the Cameroonian government and other actors have variously displayed competition for cultural knowledge (traditional, religious, diplomatic, and postmodern). Competition produces conflicts while bringing in negotiations with the State's methods and transforming the cultural boundaries of policy expertise. These cultural boundaries are unveiled when inserting the various forms of competing knowledge inside hybrid cultural frontiers.

Interpretation of data also shows that policy expertise at hybrid cultural boundaries, such as that around the Anglophone crisis, is a complex policymaking process that simultaneously involves State policy actors, institutions, and individual practices and activities at multi-social levels. Policy agents and their socio-cultural structure are interdependent. Both structures and actors coproduce the hybrid cultural politics of expertise while using various social, cultural, and social sites.

Finally, the Cameroonian state confronts alternative policy discourses without radically changing its relatively authoritative and democratic cultural methods and instead using ad hoc committees and commissions. Deliberation takes place within the framework dictated by the Head of State, President Paul Biya. Similarly, the diplomatic cultural knowledge delivered undergoes his political validation. Deliberative Cameroonian state settings, while including the participation of various members of Cameroonian society (even those in the Cameroonian diaspora), show evidence of the domination of the State's cultural ideologies. The State's cultural knowledge transforms into negotiation and argumentation practices while rejecting all forms of postmodern cultural knowledge. The Church and traditional cultural knowledge are the dominant alternative types of knowledge used by the Cameroonian state's agents.

\section{Conclusion}

The historical context of the Anglophone crisis in Cameroon has shown how various local, national, regional, international, and transnational actors shape policy expertise. First, it introduced traditional chieftaincies and rulers as social sites. Second, it displayed the roles of the Cameroonian State and foreign States' agents, committees, and commissions. It also put forward policy discourses from party leaders (the Anglophone and Francophone States' elites included), religious authorities, Anglophone (local) civil societies, and the Anglophone diaspora. Third, it brought together NGOs' and think tanks' policy discourses while putting forward the specific activities of the United Nations (UN), the European Union (EU), the UK, France, and the USA. These actors have all constituted the micro- and macro-cultural structures of policy discourses in the historical context of Cameroon's Anglophone crisis. Specifically, the historical context inserted the traditional (chieftaincies), religious, diplomatic, think-tank and governmental policy discourses as the various forms of cultural knowledge and boundaries. The Cameroonian State's inherited French, British, traditional, religious, and relatively authoritarian and democratic policy cultures shaped these various types of cultural knowledge and 
their boundaries. They also shaped relations and interactions among these experts and their knowledge, including foreign and transnational agents.

The historical context introduced historical change and structural interdependency as causal factors transforming the cultural boundaries of policy expertise. It acknowledged global historical factors such as the 'third wave' of democratization in Africa, the 'end of the Cold War' and the expansion of liberal-democratic technologies as keys to the understanding of the cultural politics of expertise. It also introduced the cultural consequences of these historical events on human rights discourses, the role of civil societies, think tanks, international organizations, and postmodern ideologies. By introducing these historical factors and transnational elements, the expertise on the Anglophone crisis brought about deeper explanations on the cultural confrontations between the Cameroonian State's experts and other policy discourses and cultural knowledge of diplomatic and religious actors, the Anglophone diaspora, Anglophone civil society, and think tanks. It disclosed experts' conflicting cultural relations and interactions at different levels of Cameroonian society (local, national, transnational). These different levels of experts' relations and cultural interactions have merged the local and global dimensions of policy discourses.

The hybrid cultural approach put forward these interconnected experts' relations and interactions as new social sites of expertise. It highlighted the various cultural locations of experts' knowledge as a research strategy while retrieving the cultural boundaries of policy expertise. This perspective shows how the interconnected experts' policy discourses from reimagined cultural and social sites (deliberative settings) confront the State's cultural knowledge. It displays experts' cultural interactions while facing their structural-political and socio-cultural bounded knowledge through the various situations (policy issues) raised by the Anglophone crisis in Cameroon.

The hybrid cultural approach to expertise has further emphasized the conflicting dialectics - 'cooperation and conflict', 'acceptance and rejection', 'action and inaction', 'dialogue and cultural resistances/inaction' - as well as the enlargement of deliberative settings and their limitations, etc. by bringing in their historical-cultural origins. From these emerged the Cameroonian State's methods, cultural behaviours, 'ways of doing', political structure (and antidemocratic nature), linked to the historical context, as producers of deadlock. New practices, such as informal meetings and private dinners and deliberations, also emerged.

The analysis shows that cultural interactions, cultural 'resistances' and 'inactions' operate as cultural characters which transform experts' activities from mere talks or policy discourses to 'negotiation', 'argumentation', 'mediation', or 'advocacy', depending on the situation or cultural context of the policy discourse. It also shows that historical partners, such as the UN and France, play significant roles and make significant attempts to transform policy discourse. At the same time, international institutions, transnational think tanks, human rights advocates, and the Anglophone diaspora policy discourses struggle inefficiently to change the State's methods and cultures.

Deliberative settings emerge from this interdependence and complexity. In contrast to the 'pure' cultural mode of interaction, based on the social interests, socio-cultural knowledge, and social needs of the citizen (Fischer, 2009), the hybrid cultural politics concedes both rationalized and non-rationalized forms of deliberation. It puts forward conflicts, contradictions, and oppositions while displaying a structural and economic interdependence between actors' policy discourses on the crisis. 
The analysis shows that the cultural politics of expertise requires the inclusion of regional, national, and transnational frontiers, including the role of the diaspora, Anglophone elites, and citizens banished through the crises. All these layers of analysis need to be considered when investigating policy expertise, defining a policy crisis, and proposing instruments to deal with it. The hybrid cultural approach inserts a relational 'historical' and cultural analysis, putting stakeholders in interdependent, dialectical socio-cultural historical social sites and structures - national, transnational, and international - while confronting both the knowledge embedded in the region's history and the political methods and the transnational cultural experience of experts with those of the globalized world. The hybrid cultural context discloses expertise as a transnational situation relating to a transnational cultural war or as struggles producing deadlocks at different levels through dialectics. At the same time, such a study of expertise immerses the researcher within interdependent socio-cultural and political structures. While following the experts' interpretation of the situation, the researcher also interprets the experts' policy discourses on the crisis and its solutions from different historical-cultural social sites (locations). Those social sites (locations) and how they interact constitute the cultural boundaries of expertise.

Bringing such a hybrid cultural context into the analysis of expertise through the Anglophone crisis in Cameroon creates a more complex cultural context of cultural knowledge where history is part of the culture. Bringing in the historical context and the hybrid cultural boundaries of expertise is part of the democratization of knowledge, nourishing both the 'war' and the 'crisis' of expertise. It explains specific historical contingencies of the cultural politics and the deliberative settings of policy deadlocks such as those around the Anglophone crisis in Cameroon.

\section{Bibliography}

Alexander, J. (2018). The societalization of social problems: Church, Paedophilia, Phone Hacking, and the Financial Crisis. American Sociological Review, 83(6), 1049-1078.

https://doi.org/10.1177/0003122418803376

Bauer, M. W., \& Gaskell, G. (Eds.) (2000). Qualitative researching with text, image and sound. SAGE Publications Ltd.

https://www.doi.org/10.4135/9781849209731

Bérard, Y. \& Crespin, R. (2015). Situation d'expertise. In: E. Henry. (Ed.), Dictionnaire critique de l'expertise: Santé, travail, environnement (pp. 297-299). Paris : Presses de Sciences Po.

Bhabha, H. (1994). The location of culture. New York and London: Routledge.

Bliesemann de Guevara, B. (2014). Studying the International Crisis Group. Third Word Quarterly, 35(4), 545-562.

https://doi.org/10.1080/01436597.2014.924060

Brown, M. (2013). Science and Democracy. Expertise, institutions, and representations. Cambridge, MA: MIT Press.

Busbridge, R. (2021). Postcolonial Political Theory. Oxford Handbook Online.

https://doi.org/10.1093/obo/9780199756223-0334 
Cefaï, D. (2013). L’expérience des publics : institution et réflexivité. EspacesTemps.net. Retrieved from: https://www.centre-max-weber.fr/IMG/pdf/cefaipublics.pdf

Callon, M., Lascoumes, P., \& Barthes, Y. (2011). Acting in an uncertain world: An essay on technical democracy. Cambridge, MA : The MIT Press.

Cefaï, D. (2020). L’expérience des problèmes publics. Paris: Éditions de l’École des Hautes Etudes en Sciences Sociales.

Cramer, K. (2016). The Politics of Resentment: Rural Consciousness in Wisconsin and the Rise of Scott Walker. Chicago, London: The University of Chicago Press.

Durnovà, A. (2019a). The politics of intimacy. Rethinking the end-of-life controversy. Ann Arbor, MI: The University of Michigan Press.

Durnovà, A. (2019b). Unpacking emotional contexts of post-truth. Critical Policy Studies, 13(4), 447-450. https://doi.org/10.1080/19460171.2019.1670222

Eyal, G. (2010). [Keynote Address, 2010 BJS Annual Conference:] How Parents of Autistic Children Became "Experts on Their Own Children": Notes toward a Sociology of Expertise. Berkeley Journal of Sociology, 54, 3-17.

http://www.jstor.org/stable/40999932

Eyal, G. (2019). The Crisis of Expertise, Cambridge: Polity Press

Fischer, F. (2006). Participatory Governance as Deliberative Empowerment: The Cultural Politics of Discursive Space. American Review of Public Administration, 36(1), 19-40. https://doi.org/10.1177\%2F0275074005282582

Fischer, F. (2009). Democracy and Expertise. Reorienting Policy Inquiry. Oxford: Oxford University Press.

Fischer F., \& Boossabong, P. (2018). Deliberative Analysis. In A. Bachtiger, J. Dryzek, J. Mansbridge and M. Warren B (Eds.). The Oxford Handbook of Deliberative Analysis. Oxford: Online publication. https://doi.org/10.1093/oxfordhb/9780198747369.013.39

Fischer, F., Durnovà, A., Torgersen, \& D. Orsini, M. (Eds.) (2017). Handbook of Critical policy studies. London: Edward Elgar.

Jackson, P. (2015). Making Sense of Making Sense. Configurational Analysis and the Double Hermeneutic. In D. Yanow \&. P. Schwartz-Shea (Eds.), Interpretation and Method. Empirical Research Methods and the Interpretive Turn (pp. 266-280). New-York \& London: ME Sharpe.

Jasanoff, S. (2005). Judgment under siege: The three body-problem of experts' legitimacy. In S. Maasen \& P. Weingart (Eds). Democratization of expertise? Exploring Novel Forms of Scientific Advice in Political Decision-Making (pp. 209-294). New York, NY: Springer

Jasanoff, S. (2011). Quality Control and Peer Review in Advisory Science. In J. Lentsch and P. Weingart (Eds.), The Politics of Scientific Advice. Institutional Design for Quality Assurance (pp. 19-35). Cambridge, New-York, Melbourne, Cambridge University Press.

Konings, P., \& Nyamnjoh, F. (1997). The Anglophone Problem in Cameroon. Journal of Modern African Studies, 35(2), 207-229.

https://doi.org/10.1017/S0022278X97002401

Konings, P., \& Jua, N. (2004). Occupation of Public Space Anglophone Nationalism in Cameroon. Cahiers d'Etudes Africaines, 175, 609-733. 
Krippendorff, K. (2018). Content Analysis. An Introduction to its Methodology. London: Sage Publications

Levitt, P. (2001). The Transnational Villagers. Berkeley, CA: University of California Press.

Milhorance, C. (2018). New Geographies of Global Policymaking. South-South Cooperation and Rural Development Strategies. New-York, NY: Routledge.

Okereke, C. N.-E. (2018). Analysing Cameroon's Anglophone Crisis. Counter Terrorist Trends and Analyses, 10(3), 8-12.

http://www.jstor.org/stable/26380430

Stone, D. (2004). Agents of knowledge. In D. Levi-Faur Oxford Handbook Online.

https://doi.org/10.1093/oxfordhb/9780199560530.001.0001

Stone, D., \& Moloney, K. (2019). The Oxford Handbook of Global Policy and Transnational Administration. Oxford: Oxford University Press.

Stone, D., \& Moloney, K. (2019). Beyond the state: Global policy and transnational administration. International Review of Public policy, 1(1), 104-118.

https://doi.org/10.4000/irpp.344

Stone, D., \& Moloney, K. (2020). Transnational Administration of Regional and Global Policies. Oxford Research Encyclopaedia of Politics.

https://doi.org/10.1093/acrefore/9780190228637.013.1734

Straßheim, H. (2017). Politics and policy expertise: towards a political epistemology. In F. Fischer, D. Torgerson, A. Durnová, \& M. Orsini (Eds.), Handbook of Critical Policy Studies (pp. 319-340). Cheltenham, U.K./Northampton, MA: Edward Elgar.

Straßheim, H. \& Beck, S. (2019). Handbook of behavioural change and public policy. In Introduction. (pp. 1-21). E. Elgar Publishing Online.

https://doi.org/10.4337/9781785367854.00005

Straßheim, H. (2020). The Rise and Spread of Behavioral Public Policy: An Opportunity for Critical Research and Self-Reflection. International Review of Public Policy. 2(1), 115-128. https://doi.org/10.4000/irpp.897

Yanow D., \& Schwartz-Shea, P. (2015). Interpretation and Method. Empirical Research Methods and the Interpretive Turn. New York, NY: Routledge.

Newspapers and Websites References:

Agbaw-Ebai, S. T. (2017, September 21). National Commission for the Promotion of Bilingualism and Multiculturalism: A failed institution. Cameroon Concord News. Retrieved from: https://www.cameroonconcordnews.com/national-commission-for-the-promotion-of-bilingualism-and-multiculturalism-a-failed-institution/

Akana, R. (2017, January 12). Cameroon Concord news). Ghogomu Paul Mingo announces end of Ad Hoc Committee mission, attacks the Consortium. Cameroon Concord News. Retrieved from: https://www.cameroonconcordnews.com/ghogomu-paul-mingo-announces-end-of-ad-hoc-committee-mission-attacks-the-consortium/

Allegrozzi, I. (2019, November5). US Cuts Cameroon Trade Privileges Over Rights Abuses. Global Pressure Needed on Executions, Unlawful Detention, and Torture. Human Rights Watch. Retrieved from: https://www.hrw.org/news/2019/11/05/us-cuts-cameroon-trade-privileges-over-rights-abuses 
Bainkong, G. (2019, February 19). Crisis in NW and SW regions: From The Beginning Was Dialogue. Cameroon Tribune. Retrieved from:

https://www.cameroon-tribune.cm/article.html/24255/en.html/crisis-in-nw-sw-regions-the-beginning-was-dialogue

Bouboutou, R-M. (2018, May 23). Cameroun: l'ambassadeur américain convoqué après avoir critiqué la gestion de la crise anglophone. Jeune Afrique. Retrieved from: https://www.jeuneafrique.com/561807/politique/cameroun-lambassadeur-americain-convoqueapres-avoir-critique-la-gestion-de-la-crise-anglophone

Cameroon: Agbor Balla rubbishes Special status, reiterates stance for two-state federation. (2020, January 21) JournalduCameroun.com. Retrieved from:

https://www.journalducameroun.com/en/cameroon-agbor-balla-rubbishes-special-status-reiterates-stance-for-two-state-federation

Cameroon: Situation humanitaire 'urgente' selonl'ONU (2019, May13). JeuneAfrique. Retrieved from: https://www.jeuneafrique.com/774225/politique/cameroun-situation-humanitaire-urgenteselon-lonu/

Cameroon US Embassy (2018, November 6). U.S. Concerned Over Violence Uptick in Cameroon. Retrieved from: https://cm.usembassy.gov/u-s-concerned-over-violence-uptick-in-cameroon/

Cameroon State. President BIYA Holds Talks with UN High Commissioner for Human Rights. Retrieved from:

https://www.prc.cm/en/news/audiences/3468-president-biya-holds-talks-with-un-high-commissioner-for-human-rights. Accessed: 20 June 2021.

Crise anglophone au Cameroun:la Suisse en médiatrice (2019, June 28). Jeune Afrique. Retrieved from: https://www.jeuneafrique.com/795222/politique/crise-anglophone-au-cameroun-la-suisse-enmediatrice/

Crise anglophone au Cameroun: le club des ex-présidents fait pression sur Paul Biya. (2019, July 29). Jeune Afrique. Retrieved from https://www.jeuneafrique.com/mag/809579/politique/criseanglophone-au-cameroun-le-club-des-ex-presidents-fait-pression-sur-paul-biya/

Dougueli, G. (2019, September 26). Crisis Negotiator. Cameroon: Ten things to know about prime minister Joseph Dion Ngute. The Africa Report. Retrieved from: https://www.theafricareport.com/17734/cameroon-ten-things-to-know-about-prime-ministerjoseph-dion-ngute

Foute, F. (2019, October 2). Cameroun - Akere Muna: " Il faut reprendre le dialogue national sur de nouvelles bases». Jeune Afrique. Retrieved from: https://www.jeuneafrique.com/837476/politique/cameroun-akere-muna-il-faut-reprendre-le-dialogue-national-sur-de-nouvelles-bases/

Haig, T. (2019, September 24). Canadians' trust in science appears to be eroding: poll. Radio Canada International. Retrieved from:

International Crisis Group (2018, April 25). Cameroon Anglophone Crisis: How the Catholic Church can Promote Dialogue. Retrieved from:

https://www.crisisgroup.org/africa/central-africa/cameroon/b138-cameroons-anglophone-crisishow-catholic-church-can-promote-dialogue

Loh, C. (2019, May 10). North-West: P.M Dion Ngute Crusading For Return to Normalcy. Cameroon Tribune Retrieved from:

https://www.cameroon-tribune.cm/article.html/25630/fr.html/north-west-p.m-dion-ngute-crusading-for-return-normalcy 
National Commission for the Promotion of Bilingualism and Multiculturalism members (page: https://www.ncpbm.cm/en/commission/members. Accessed : 20 April 2021.

Teke, E. (2017, September 3). SCNC and The Cameroon Anglophone Civil Society Banned. Crtv web archive. Retrieved from:

https://web.archive.org/web/20170903072226/http://crtv.cm/fr/latest-news/top-news-24/scncand-the-cameroon-anglophone-civil-society-consortium-banned--18545.htm

The National Commission for the Promotion of Bilingualism and Multiculturalism Keeping Promises Cameroon Tribune (2017, March 17). Cameroon Tribune. Retrieved from https://www.cameroontribune.cm/article.html/6740/fr.html/national-commission-for-the-promotion-of-bilingualismmulticulturalism-keeping-promises

US Ambassador to Cameroon Peter Henry Barlerin looks for solutions to the Anglophone Crisis with Emeritus Cardinal Tumi, Barrister Agbor Balla and a host of others including a government representative. (n.d). Henriett Thatcher's lounge. Retrieved from: https://www.henriettethatchers.com/2018/04/us-ambassador-to-cameroon-peter-henry.html

\section{Appendix}

\section{Annex files}

The tables below present the core materials and key references in data sets that went through investigation. Appendix 1.A is the presentation of national newspapers in which various actors framed the Anglophone crisis as a policy issue between October 2016 and December 2016. Appendix 1.B lists media, files and newspapers' titles retrieved from the two explored media database. Appendix 2 presents the reports' resources published by think thanks and international NGOs which also served the analysis. A Complementary data set of coded interviews occurs in Appendix 3.

Appendix 1: A National Newspapers analyzed at the beginning of the crisis (October- December 2016)

\begin{tabular}{|l|l|l|l|}
\hline \multicolumn{2}{|l|}{ Party Policy discourses } \\
\hline Newspaper & Specific sources & Type, Ideology & Audience \\
\hline Le Jour & $\begin{array}{l}\text { November 16, 2016 } \\
\text { November 23, 2016, } \\
n^{\circ} 2317 \\
\text { November 25, 2016, } \\
n^{\circ} 2316\end{array}$ & $\begin{array}{l}\text { French-language 'private' } \\
\text { newspaper, created } \\
\text { in September 2007. politi- } \\
\text { cal scandals and focus on } \\
\text { government activities }\end{array}$ & $\begin{array}{l}\text { National and internation- } \\
\text { al publics ; } \\
\text { On https://ekiosque.cm/ } \\
\text { lejour }\end{array}$ \\
$\begin{array}{l}\text { Le } \\
\begin{array}{l}\text { Quotidien } \\
\text { le } \\
\text { l'économie } \\
n^{\circ} 01196\end{array}\end{array}$ & $\begin{array}{l}\text { French-language 'private' } \\
\text { newspaper; has a focus } \\
\text { on Economic and Finance } \\
\text { information }\end{array}$ & $\begin{array}{l}\text { National and international } \\
\text { audience; } \\
\text { Facebook page: https:// } \\
\text { www.facebook.com/lecono- } \\
\text { miecmr/ }\end{array}$ \\
\hline
\end{tabular}




\begin{tabular}{|c|c|c|c|}
\hline Le Messager & $\begin{array}{l}\text { December } 13,2016, \\
n^{\circ} 4722 \\
\text { November } 25,2016, \\
n^{\circ} 4710\end{array}$ & $\begin{array}{l}\text { 'Independent' French-lan- } \\
\text { guage newspaper, created } \\
\text { in 1979. Played a signifi- } \\
\text { cant role in the democrati- } \\
\text { zation process during the } \\
\text { 1990s from the diaspora } \\
\text { social site }\end{array}$ & $\begin{array}{l}\text { Cameroonian diasporas, } \\
\text { national and international } \\
\text { audience, party leaders }\end{array}$ \\
\hline L'Action & $\begin{array}{l}\text { December 07, 2016, } \\
n^{\circ} 1086\end{array}$ & $\begin{array}{l}\text { The State ruling party (the } \\
\text { CPDM) policy journal }\end{array}$ & $\begin{array}{l}\text { National, CPDM members } \\
\text { http://www.rdpcpdm.cm/ } \\
\text { le-journal-laction/ }\end{array}$ \\
\hline $\begin{array}{l}\text { Quotidien } \\
\text { Emergence }\end{array}$ & $\begin{array}{l}\text { November } 30,2016, \\
n^{\circ} 886 \\
\text { December 5, 2016, } \\
n^{\circ} 889\end{array}$ & $\begin{array}{l}\text { Bilingual 'private' newspa- } \\
\text { per. } \\
\text { Publish general infor- } \\
\text { mation with a focus on } \\
\text { government action and } \\
\text { development issues } \\
\end{array}$ & $\begin{array}{l}\text { National, international and } \\
\text { diasporas audience. } \\
\text { Facebook: https:// } \\
\text { www.facebook.com/ } \\
\text { Journal-EMER- } \\
\text { GENCE-126657427356060 }\end{array}$ \\
\hline $\begin{array}{l}\text { La Nouvelle } \\
\text { expression }\end{array}$ & $\begin{array}{l}\text { December 13, 2016, } \\
n^{\circ} 4374\end{array}$ & $\begin{array}{l}\text { French-language 'private' } \\
\text { newspaper, created in } \\
\text { February 1991, during the } \\
\text { democratization process. } \\
\text { Publish general informa- } \\
\text { tion }\end{array}$ & $\begin{array}{l}\text { national and international } \\
\text { audience }\end{array}$ \\
\hline The star & $\begin{array}{l}\text { December 5, 2016, } \\
\text { Vol. 2, n }{ }^{\circ} 406\end{array}$ & $\begin{array}{l}\text { English-language newspa- } \\
\text { per }\end{array}$ & \\
\hline $\begin{array}{l}\text { Ouest } \\
\text { Littoral }\end{array}$ & $\begin{array}{l}\text { December 13, 2016, } \\
n^{\circ} 430\end{array}$ & $\begin{array}{l}\text { French-language 'private' } \\
\text { newspaper; critical towards } \\
\text { Cameroonian government }\end{array}$ & $\begin{array}{l}\text { National audience } \\
\text { Facebook https://www.fa- } \\
\text { cebook.com/groups/29887 }\end{array}$ \\
\hline La Nouvelle & $\begin{array}{l}\text { December 5, 2016, } \\
n^{\circ} 360\end{array}$ & $\begin{array}{l}\text { French-language 'private' } \\
\text { newspaper }\end{array}$ & National \\
\hline The Post & $\begin{array}{l}\text { December 6, 2016, } \\
n^{\circ} 1070\end{array}$ & $\begin{array}{l}\text { English-language 'private' } \\
\text { newspaper, } \\
\text { Created in } 1996 .\end{array}$ & $\begin{array}{l}\text { national and international } \\
\text { audience } \\
\text { https://www.thepostnp. } \\
\text { com }\end{array}$ \\
\hline $\begin{array}{l}\text { The Guard- } \\
\text { ian Post }\end{array}$ & $\begin{array}{l}\text { December 8, 2016, } \\
n^{\circ} 1072\end{array}$ & $\begin{array}{l}\text { English-language 'private' } \\
\text { daily newspaper }\end{array}$ & $\begin{array}{l}\text { national and international } \\
\text { audience } \\
\text { https://m.facebook.com/ } \\
\text { theguardianpostdaily/ } \\
\text { website: http://theguardi- } \\
\text { anpostcameroon.com }\end{array}$ \\
\hline
\end{tabular}




\begin{tabular}{|c|c|c|c|}
\hline \multicolumn{4}{|c|}{ Cameroonian Government policy discourses } \\
\hline $\begin{array}{l}\text { Cameroon } \\
\text { Tribune }\end{array}$ & $\begin{array}{l}\text { November 25, 2016; } \\
\text { December 12, 2016; } \\
\text { December 25, 2016; } \\
\text { December 5, } 2016\end{array}$ & $\begin{array}{l}\text { Bilingual 'public' bilingual } \\
\text { newspaper. } \\
\text { It was created in } 1974 .\end{array}$ & $\begin{array}{l}\text { National and international } \\
\text { audience; } \\
\text { https://www.cameroon- } \\
\text { tribune.cm }\end{array}$ \\
\hline $\begin{array}{l}\text { La Nouvelle } \\
\text { Expression }\end{array}$ & $n^{\circ} 4331$ & (see above) & (see above) \\
\hline La Météo & $\begin{array}{l}\text { November 7, 2016, } \\
n^{\circ} 823\end{array}$ & $\begin{array}{l}\text { French-language 'private } \\
\text { newspaper'; } \\
\text { Focus on politics }\end{array}$ & $\begin{array}{l}\text { national and international } \\
\text { audience } \\
\text { https://ekiosque.cm/jour- } \\
\text { nal-126270-La-Météo- }\end{array}$ \\
\hline La Météo & $\begin{array}{l}\text { December 5, 2016, } \\
n^{\circ} 831\end{array}$ & $-/ /-$ & $-/ /-$ \\
\hline $\begin{array}{l}\text { Le Quo- } \\
\text { tidien de } \\
\text { l'économie } \\
\end{array}$ & $\mathrm{n}^{\circ} 01194$ & (see above) & (see above) \\
\hline Le Jour & $\begin{array}{l}\text { December 1, 2016, } \\
n^{\circ} 2323\end{array}$ & (see above) & (see above) \\
\hline $\begin{array}{l}\text { Kalara } \\
\text { Journal }\end{array}$ & $\begin{array}{l}\text { November 14, 2016, } \\
n^{\circ} 174\end{array}$ & $\begin{array}{l}\text { French-language journal } \\
\text { Relates court cases and hu- } \\
\text { man rights claims/abuses }\end{array}$ & $\begin{array}{l}\text { National, international. } \\
\text { Facebook: https://www.fa- } \\
\text { cebook.com/Journalkalara/ } \\
\text { Website: https://kalara- } \\
\text { hebdo.net }\end{array}$ \\
\hline Le Jour & December 13, 2016 & $\begin{array}{l}\text { A French-language news- } \\
\text { paper created in September } \\
2007 .\end{array}$ & Politicians, civil societies \\
\hline $\begin{array}{l}\text { The-Guardi- } \\
\text { an Post }\end{array}$ & $\mathrm{n}^{\circ} 1071$ & $\begin{array}{l}\text { English-language newspa- } \\
\text { per, created in }\end{array}$ & $\begin{array}{l}\text { national and international } \\
\text { audience } \\
\text { https://m.facebook.com/ } \\
\text { theguardianpostdaily/ } \\
\text { website: http://theguardi- } \\
\text { anpostcameroon.com }\end{array}$ \\
\hline \multicolumn{4}{|c|}{ Religious discourses } \\
\hline $\begin{array}{l}\text { Cameroon } \\
\text { Tribune }\end{array}$ & $\begin{array}{l}\text { December 08, 2016; } \\
\text { December 13, } 2016\end{array}$ & (see above) & (see above) \\
\hline \multicolumn{4}{|c|}{ Civil society policy discourses } \\
\hline Le Soir & \begin{tabular}{|l} 
December 7, 2016, \\
$\mathrm{n}^{\circ} 595$
\end{tabular} & & \\
\hline $\begin{array}{l}\text { Quotidien } \\
\text { Emergence }\end{array}$ & $\begin{array}{l}\text { November 18, 2016, } \\
n^{\circ} 878 \\
\text { December 2, 2016, } \\
n^{\circ} 888\end{array}$ & (see above) & (see above) \\
\hline
\end{tabular}




\begin{tabular}{|c|c|c|c|}
\hline The Sun & $\begin{array}{l}\text { December 12, 2016, } \\
\mathrm{n}^{\circ} 0411\end{array}$ & $\begin{array}{l}\text { Cameroon English-lan- } \\
\text { guage newspaper. } \\
\text { General information; focus } \\
\text { on Government activities }\end{array}$ & $\begin{array}{l}\text { National and international } \\
\text { audience. Particularly } \\
\text { followed by Anglophone } \\
\text { diasporas. } \\
\text { Facebook: https://www. } \\
\text { facebook.com/thesunnews- } \\
\text { papercameroon/ }\end{array}$ \\
\hline $\begin{array}{l}\text { Cameroon } \\
\text { Tribune }\end{array}$ & $\begin{array}{l}\text { November 21, 2016; } \\
\text { December 6, 2016; } \\
\text { December 13, } 2016\end{array}$ & (see above) & (see above) \\
\hline The Post & $\begin{array}{l}\text { October 21, 2016, } \mathrm{n}^{\circ} \\
01768\end{array}$ & (see above) & (see above) \\
\hline Repères & $\begin{array}{l}\text { December 7, 2016, } \\
n^{\circ} 504\end{array}$ & CPDM party policy journal & $\begin{array}{l}\text { National, international. } \\
\text { Facebook: https://m.face- } \\
\text { book.com/journalreperes/ }\end{array}$ \\
\hline $\begin{array}{l}\text { Kalara } \\
\text { Journal }\end{array}$ & $\begin{array}{l}\text { October 31, 2016, } \\
n^{\circ} 172\end{array}$ & (see above) & (see above) \\
\hline Le Messager & $\begin{array}{l}\text { October 19, 2016, } \\
\mathrm{n}^{\circ} 4683\end{array}$ & (see above) & (see above) \\
\hline $\begin{array}{l}\text { The Guard- } \\
\text { ian Post }\end{array}$ & $\begin{array}{l}\text { December 1, 2016, } \mathrm{n}^{\circ} \\
\text { 1067; November 21, } \\
2016, \mathrm{n}^{\circ} 1059 . \\
\\
\text { August } 31,2016, \\
\mathrm{n}^{\circ} 1002 ; \text { September 5, } \\
2016, \mathrm{n}^{\circ} 1005 \\
\end{array}$ & (see above) & (see above) \\
\hline \multicolumn{4}{|c|}{ International organizations and diasporas discourses } \\
\hline $\begin{array}{l}\text { Quotidien } \\
\text { Emergence }\end{array}$ & $\begin{array}{l}\text { November } 30,2016, \\
n^{\circ} 886 ; \text { December } 5, \\
2016, n^{\circ} 889\end{array}$ & (see above) & (see above) \\
\hline $\begin{array}{l}\text { La Nouvelle } \\
\text { expression }\end{array}$ & $\begin{array}{l}\text { December 13, 2016, } \\
n^{\circ} 4374\end{array}$ & (see above) & (see above) \\
\hline The Star & $\begin{array}{l}\text { December 5, 2016, } \\
\text { vol2_n406 }\end{array}$ & (see above) & (see above) \\
\hline $\begin{array}{l}\text { Ouest Lit- } \\
\text { toral }\end{array}$ & $\begin{array}{l}\text { December 13, 2016, } \\
\mathrm{n}^{\circ} 430\end{array}$ & (see above) & (see above) \\
\hline La Nouvelle & $\begin{array}{l}\text { December 5, 2016, } \\
n^{\circ} 360\end{array}$ & (see above) & (see above) \\
\hline The Post & $\begin{array}{l}\text { December 6, 2016, } \\
n^{\circ} 1070\end{array}$ & & \\
\hline $\begin{array}{l}\text { The Guard- } \\
\text { ian Post }\end{array}$ & $\begin{array}{l}\text { December 8, 2016, } \\
n^{\circ} 1072\end{array}$ & (see above) & (see above) \\
\hline Mutations & $\begin{array}{l}\text { November } 30,2016, \\
n^{\circ} 4275\end{array}$ & (see above) & (see above) \\
\hline
\end{tabular}


Appendix 1.B. Data set 2 (files and articles retrieved from media database)

\begin{tabular}{|l|l|l|}
\hline Database & Retrieved files & Analyzed media/files \\
\hline $\begin{array}{l}\text { Jeune Afrique } \\
\text { Digital }\end{array}$ & $\begin{array}{l}\text { Dossier: Cameroun: 'les véritables } \\
\text { victimes de la crise anglophone' }\end{array}$ & $\begin{array}{l}\text { https://www.jeuneafrique.com/dos- } \\
\text { siers/cameroun-les-veritables-vic- } \\
\text { times-de-la-crise-anglophone/ }\end{array}$ \\
\hline $\begin{array}{l}\text { Wikipedia } \\
\text { (via Google) }\end{array}$ & Via Google & $\begin{array}{l}\text { https://fr.wikipedia.org/wiki/Cri- } \\
\text { se_anglophone_au_Cameroun\#cite_ } \\
\text { note-35 }\end{array}$ \\
\hline media data set & $\begin{array}{l}\text { Text searched: Crise anglophone } \\
\text { au Cameroun / request all types of } \\
\text { sources / All regions / all languages } \\
\text { Period: January 2018 - January } \\
2020 \\
140 \text { articles retrieved on January 27, } \\
2020,20: 10\end{array}$ & $\begin{array}{l}\text { JournalduCameroun.com; Sputnik } \\
\text { French News service; Cameroon } \\
\text { Tribune; Le Point.fr; AllAfrica; AFP; } \\
\text { Agence Ecofin; Investir au Cam- } \\
\text { eroun; Koaci.com; Jeune Afrique. } \\
\text { com; Xinhua French News Service; } \\
\text { Cameroon-info.net; Le Quotidien du } \\
\text { Peuple; Les depeches de Brazzaville; } \\
\text { Ici Lome.com; APANEWS; Journal } \\
\text { de Brazza.com; AllAfrica; Le Point } \\
\text { Afrique; Foreign Affairs; La Tribune; } \\
\text { La lettre du continent; } \\
\text { Agence congolaise de presse; Mali. } \\
\text { Actu.net; Camer.be } \\
\text { La Croix; Le Pays; Alwiida.com } \\
\text { Ats Information.com }\end{array}$ \\
& &
\end{tabular}

Appendix 2. Think tank and International NGOs resources

\begin{tabular}{|l|l|}
\hline Name & References / retrieved documents \\
\hline International Crisis Group & $\begin{array}{l}\text { (7 documents) } \\
\text { Reports }{ }^{\circ} \text { 130, } 250 \text { released in } 2017 . \\
\text { Report } n^{\circ} \text { 138, April 25, 2018. } \\
\text { Statements on December 21, 2017, and Sep- } \\
\text { tember 17, 2018. } \\
\text { 'Journeys', July 27, 2018 } \\
\text { Video report, May 2, 2019 }\end{array}$ \\
\hline La Vigie & $\begin{array}{l}\text { (1 document) } \\
\text { 'La crise anglophone au Cameroun: raisons, en- } \\
\text { jeux et solutions' } \\
\text { published on November 23, 2018 }\end{array}$ \\
\hline
\end{tabular}


Appendix 3: Interviews / conversations codes

\begin{tabular}{|l|l|l|}
\hline Policy discourse & Date of interview & Code \\
\hline French diplomat & 29 September 2017 & FRDIPD-20092017 \\
\hline US diplomat & 14 June 2019 & USDIPD-14062019 \\
\hline UN diplomat & 14 June 2019 & UNDIPD-14062019 \\
\hline UE diplomat & 14 June 2019 & UEDIPD-14062019 \\
\hline MRC party leader & 14 June 2019 & MRCPPPD - 14062019 \\
\hline PCRN party leader & 18 Janvier 2019 & PCRNPD-18012019 \\
\hline Archbishop & 14 June 2019 & ARCH-14062019 \\
\hline Member of government & 24 May 2019 & MG2PD-24052019 \\
\hline Independent journalist & 20 February 2021 & INDJOURPD- 7092019 \\
\hline CACS leader & 20 April 2021 & CACSCPD-20042021 \\
\hline CACS leader continued & 15 June 2021 & CACSPD-15062021 \\
\hline
\end{tabular}

